\title{
HLA-DQ2 and -DQ8 haplotypes frequency and diagnostic utility in celiac disease patients of Gaza strip, Palestine
}

\author{
Basim M. Ayesh ${ }^{1}$ (D) Eman Kh. Zaqout ${ }^{2} \cdot$ Maged M. Yassin $^{3}$
}

Received: 1 July 2017/ Accepted: 6 September 2017/Published online: 15 November 2017

(c) The Author(s) 2017. This article is an open access publication

\begin{abstract}
Purpose Celiac disease (CD) diagnosis can be established by serological and small bowel biopsy (SBB), while absence of HLA-DQ2 and -DQ8 haplotypes excludes the disease. The present study aims at evaluating the diagnosis of a representative sample of pediatric and adult CD patients of Gaza strip in light of DQ2 and DQ8 haplotypes expression.

Methods Unrelated CD patients $(n=101)$ and matched healthy controls $(n=97)$ were genotyped for $D Q A 1 * 05$, $D Q B 1 * 02$ and $D Q B 1 * 03: 02$ alleles by allele-specific realtime PCR. The diagnosis was re-evaluated according to the patient laboratory tests and HLA-DQ genotype.

Results The diagnosis of 35 patients who have been managed for CD could not be confirmed. Twenty-five of them were diagnosed upon their clinical presentation only. The remaining were either negative for serological and SBB tests or negative for HLA-DQ haplotypes. The HLADQ alleles were negative in 4 SBB and one Anti-EMA
\end{abstract}

Basim M. Ayesh

Bm.ayesh@alaqsa.edu.ps

Eman Kh. Zaqout

ekzaqout@live.com

Maged M. Yassin

myassin@mail.iugaza.edu

1 Department of Laboratory Medical Sciences, Alaqsa University, P.O. Box 4051, Gaza, Palestine

2 Forensic Lab, Palestinian Ministry of Justice, Gaza, Palestine

3 Faculty of Medicine, The Islamic University of Gaza, Gaza, Palestine positive patients. The frequency of DQ2 and DQ8 haplotypes among the remaining 65 confirmed cases was 70.8 and $15.4 \%$, respectively, compared to 17.5 and $27.8 \%$ in the controls. The $D Q B 1 * 02$ allele was the most common in the cases $(84.6 \%)$ followed by $D Q A 1 * 05$ allele $(80 \%)$ and $D Q B 1 * 03: 02$ allele $(20 \%)$. The $D Q A 1 * 05$ allele was commonest in the control group $(54.6 \%)$ followed by $D Q B 1 * 02$ allele $(42.3 \%)$ and $D Q B 1 * 03: 02$ allele $(28.9 \%)$. Conclusions Absence of HLA-DQ2 and HLA-DQ8 genotyping in the workup of patients may result in CD misdiagnosis, particularly in a setting with poor histopathological diagnostic capacity.

Keywords Celiac disease $\cdot$ HLA-DQ2 $\cdot$ HLA-DQ8 $\cdot$ Gaza strip

\section{Introduction}

Celiac disease (CD) is a chronic small intestinal immunemediated enteropathy triggered by ingestion of a complex protein, gluten, present in cereals such as wheat, barley and rye in genetically predisposed individuals [1]. The most important determinant of genetic susceptibility for CD is the presence of human leukocyte antigen-DQ (HLA-DQ) heterodimers DQ2 (encoded by alleles DQA1*0501 and $D Q B 1^{* 0201)}$ and HLA-DQ8 (encoded by alleles $D Q A 1 * 0301$ and $D Q B 1 * 0302$ ) [2-4]. HLA-DQ2 is present in more than $90 \%$ and HLA-DQ8 in about $5 \%$ of patients with CD [2, 5-7].

Expression of HLA-DQ2 or HLA-DQ8 molecules is necessary but not sufficient to cause $\mathrm{CD}$. While about $20-40 \%$ of the white population carries HLA-DQ2, only $1 \%$ may develop the disease [7, 8]. Accordingly, addition of HLA-DQ typing to serological tests (anti-tissue 
transglutaminase enzyme antibodies tTG and Anti-endomysial antibodies EMA) does not improve the diagnostic capacity, because of its low positive predictive value $[8,9]$. On the other hand, individuals lacking HLA-DQ2 and -DQ8 expression are unlikely to have CD with a negative predictive value of $>99 \%[4,8,9]$. Therefore, the main role of HLA-DQ typing in the diagnosis of $\mathrm{CD}$ is to exclude the disease $[6,10,11]$. In particular, application of HLA-DQ2 and -DQ8 typing is recommended to exclude $\mathrm{CD}$ in patients with equivocal small bowel biopsy (SBB) finding or those following a Gluten-free diet $[7,12,13]$ and patients with non-celiac gluten sensitivity $[1,14,15]$. HLA-DQ2 and -DQ8 typing is also recommended for CD screening in high-risk individuals including first-degree relatives of a confirmed case and patients with autoimmune and non-autoimmune conditions known to be associated with $\mathrm{CD}$, such as type 1 diabetes mellitus, Down syndrome, and Turner syndrome [7, 16].

In Gaza strip, a total of $594 \mathrm{CD}$ patients were registered and managed at Ard El Insan Palestinian Benevolent Association at the time this study was carried out. Their diagnosis did not include HLADQ genotyping and did not follow a standard protocol. To the best of our knowledge, only one published study discussed the immunodiagnosis of pediatric CD patients in Gaza strip [17]. Therefore, the aim of the present study was to evaluate the diagnosis of a representative sample of pediatric and adult CD patients of Gaza strip in light of DQ2 and DQ8 haplotypes.

\section{Materials and methods}

\section{Study design and population}

The study is a case-control study of 101 unrelated CD pediatric and adult patients (31 males and 70 females; mean age $\pm \mathrm{SD}$ is $22.9 \pm 15.8$ years) and 97 healthy subjects, matched in age and sex (27 males and 70 females; mean age $\pm \mathrm{SD}$ is $22.9 \pm 15.8$ years). All cases were collected from two centers of Ard El Insan Palestinian Benevolent Association in Gaza and KhanYunis governorates. The patients listed in the two centers were subdivided into three age groups from which representative numbers of patients were randomly recruited ( 50 were $<20$ years; 35 were $20-40$ years; 16 were $>40$ years). The control group comprised unrelated healthy subjects with no symptoms of $\mathrm{CD}$ or gastrointestinal tract complains, recruited from the general population. Gender and age of controls was matched to the patients (31 males and 70 females; mean age \pm SD is $23.5 \pm 15.7$ years).

\section{Sample collection and genomic DNA Extraction}

About $3 \mathrm{ml}$ of venous EDTA-anticoagulated blood were drawn and stored at $2-8{ }^{\circ} \mathrm{C}$ until genomic DNA extraction. DNA was extracted, within 3 days, from $300 \mu$ whole blood samples using the Wizard Genomic DNA Purification kit (Promega, USA) according to the manufacturer's instructions. The concentrations of DNA samples were determined spectrophotometrically, and adjusted to $15 \mathrm{ng} /$ $\mu \mathrm{L}$ prior to the PCR reactions.

\section{HLA DQ2 and DQ8 genotyping}

Sequence-specific primers for the $D Q A 1 * 05, D Q B 1 * 02$, $D Q B 1 * 03: 02$ alleles and the Human Growth Hormone (HGH) endogenous control were previously described [18]. Separate $20 \mu \mathrm{l}$-amplification reactions were setup for each allele together with the HGH endogenous control. The reactions comprised $45 \mathrm{ng}$ DNA, 1X EVA-Green Master Mix (Qiagen, Germany) and the proper primers concentration (Table 1). The amplification reactions were performed in the Rotor-Gene Q real-time PCR system (Qiagene, Germany) using a touchdown temperature profile (Table 2). The allele specific amplicons were identified with high resolution melting analysis (HRM). Results produced by the real-time PCR were called positive or negative based on the presence of the correct $T_{\mathrm{m}}$ (Table 3 ). The specificity of real-time PCR assay was further verified by loading some of the positive samples onto $2 \%$ agarose gel, stained with ethidium bromide and visualized using a UV-gel documentation system to rule out nonspecific amplification.

\section{Data collection and analysis}

Data was obtained from the patients' medical records in Ard El Insan Palestinian Benevolent Association. The data focused on the results of laboratory tests performed to establish CD diagnosis (such as Anti-EMA, Anti-tTG and SBB).

Statistical analysis was carried out using the Statistical Package for Social Sciences (SPSS) for Windows, version

Table 1 Final concentrations of primers used in allele specific PCRs

\begin{tabular}{llll}
\hline & \multicolumn{2}{l}{ Primer Conc. $(\mu \mathrm{M})$} \\
\cline { 2 - 4 } & $D Q A 1 * 05$ & $D Q B 1 * 02$ & $D Q B 1 * 03: 02$ \\
\hline AS primer & 0.6 & 0.3 & 0.45 \\
IC primer & 0.3 & 0.3 & 0.21 \\
\hline
\end{tabular}

$A S$ allele specific, $I C$ internal control 
Table 2 Temperature profile for amplification and high resolution melting analysis of $D Q A 1 * 05, D Q B 1 * 02$ and $D Q B 1 * 03: 02$ alleles

\begin{tabular}{|c|c|c|c|c|c|c|}
\hline \multirow[t]{2}{*}{ Amplification program } & \multicolumn{3}{|c|}{$D Q A 1 * 05$} & \multicolumn{3}{|c|}{$D Q B 1 * 02$ and $D Q B 1 * 03: 02$} \\
\hline & Temp & Time & Cycles & Temp & Time & Cycles \\
\hline Hold & $95^{\circ} \mathrm{C}$ & $5 \mathrm{~min}$ & 1 & $95^{\circ} \mathrm{C}$ & $5 \mathrm{~min}$ & 1 \\
\hline \multirow[t]{3}{*}{ Amplification 1} & $95^{\circ} \mathrm{C}$ & $20 \mathrm{~s}$ & 20 & $95^{\circ} \mathrm{C}$ & $20 \mathrm{~s}$ & 10 \\
\hline & $65^{\circ} \mathrm{C}$ & $30 \mathrm{~s}$ & & $68^{\circ} \mathrm{C}$ & $30 \mathrm{~s}$ & \\
\hline & $72{ }^{\circ} \mathrm{C}$ & $30 \mathrm{~s}$ & & $72{ }^{\circ} \mathrm{C}$ & $30 \mathrm{~s}$ & \\
\hline \multirow[t]{3}{*}{ Amplification 2} & $95^{\circ} \mathrm{C}$ & $20 \mathrm{~s}$ & 20 & $95^{\circ} \mathrm{C}$ & $20 \mathrm{~s}$ & 25 \\
\hline & $60^{\circ} \mathrm{C}$ & $30 \mathrm{~s}$ & & $63{ }^{\circ} \mathrm{C}$ & $30 \mathrm{~s}$ & \\
\hline & $72{ }^{\circ} \mathrm{C}$ & $30 \mathrm{~s}$ & & $72{ }^{\circ} \mathrm{C}$ & $30 \mathrm{~s}$ & \\
\hline \multirow[t]{2}{*}{ HRM } & \multicolumn{3}{|c|}{$80-90{ }^{\circ} \mathrm{C}$} & \multicolumn{3}{|c|}{$82-90{ }^{\circ} \mathrm{C}$} \\
\hline & \multicolumn{3}{|c|}{$0.1^{\circ} \mathrm{C}$ increments for $2 \mathrm{~s}$} & \multicolumn{3}{|c|}{$0.1^{\circ} \mathrm{C}$ increments for $2 \mathrm{~s}$} \\
\hline
\end{tabular}

Table $3 \mathrm{~T}_{\mathrm{m}}$ specific for amplicons of $D Q A 1 * 05, D Q B 1 * 02$ and $D Q B 1 * 03: 02$ alleles and HGH internal control

\begin{tabular}{|c|c|c|c|c|}
\hline \multirow[t]{2}{*}{ Allele } & \multicolumn{4}{|c|}{$T_{\mathrm{m}}\left({ }^{\circ} \mathrm{C}\right)$} \\
\hline & Mean & Min. & Max. & $\mathrm{SD}$ \\
\hline$D Q A 1 * 05$ & 82.4 & 81.6 & 83.2 & 0.3 \\
\hline$D Q B 1 * 02$ & 87.5 & 87.1 & 88.3 & 0.3 \\
\hline$D Q B 1 * 03: 02$ & 87.7 & 87.1 & 88.5 & 0.3 \\
\hline HGH & 85.8 & 85.2 & 86.6 & 0.3 \\
\hline
\end{tabular}

20. Chi-square test was applied to establish statistical significance with $95 \%$ confidence $(P$ value $\leq 0.05)$.

\section{Results}

\section{Clinical data and diagnostic tests}

Table 4 summarizes the laboratory tests performed to establish diagnosis of the cases as registered in their medical records. The results of HLA typing test, performed in this study are also listed. All cases that were diagnosed by Anti-EMA and/or Anti-tTG in addition to SBB (nine cases) were positive for HLA-DQ2, -DQ8 haplotypes or one of their alleles. The diagnosis of 25 cases, surprisingly did not rely upon any laboratory test, but was solely based on their clinical presentation.

Eight patients had neither DQ2 nor DQ8 haplotypes. Their diagnosis is thus excluded, particularly as four of them were diagnosed by SBB alone, three patients were diagnosed by their clinical pictures and one patient was diagnosed by an Anti-EMA test (Table 4).

In total, the diagnosis of 36 cases could not be confirmed because they lack any laboratory test, they were negative for all diagnostic tests, or they had a negative HLA typing test. Hence, the frequency of DQ2 and DQ8 haplotypes and their associated alleles was studied in the remaining 65 patients who were positive for a serological test and/or
Table 4 Diagnostic test performed for the case group

\begin{tabular}{|c|c|c|c|}
\hline \multirow[t]{2}{*}{ Previous tests } & & \multicolumn{2}{|l|}{ HLA result $^{\mathrm{a}}$} \\
\hline & & Positive & Negative \\
\hline \multicolumn{4}{|l|}{ Frequency $(\%)$} \\
\hline \multicolumn{4}{|l|}{ Anti-EMA } \\
\hline \multicolumn{4}{|l|}{ Yes } \\
\hline Positive & $41(40.6 \%)$ & $40(97.6 \%)$ & $1(2.4 \%)$ \\
\hline Negative & $6(5.9 \%)$ & $6(100 \%)$ & 0 \\
\hline No & $54(53.5 \%)$ & $54(100 \%)$ & 0 \\
\hline \multicolumn{4}{|l|}{ Anti-tTG } \\
\hline \multicolumn{4}{|l|}{ Yes } \\
\hline Positive & $7(6.9 \%)$ & $7(100 \%)$ & 0 \\
\hline Negative & $1(1 \%)$ & $1(100 \%)$ & 0 \\
\hline No & $93(92.1 \%)$ & $93(100 \%)$ & 0 \\
\hline \multicolumn{4}{|l|}{ Biopsy } \\
\hline \multicolumn{4}{|l|}{ Yes } \\
\hline Positive & $31(30.7 \%)$ & $27(87.1 \%)$ & $4(12.9 \%)$ \\
\hline Negative & $5(5 \%)$ & $5(100 \%)$ & 0 \\
\hline No & $65(64.4 \%)$ & $65(100 \%)$ & 0 \\
\hline \multicolumn{4}{|c|}{ Anti-EMA and/or Anti-tTG + Biopsy } \\
\hline Yes & $9(8.9 \%)$ & $9(100 \%)$ & 0 \\
\hline No & $92(91.1 \%)$ & $92(100 \%)$ & 0 \\
\hline $\operatorname{Non}^{b}$ & $25(24.8 \%)$ & $22(88 \%)$ & $3(12 \%)$ \\
\hline
\end{tabular}

${ }^{\text {a Positive for HLA } D Q A 1 * 05, D Q B 1 * 02 \text { or } D Q B 1 * 03: 02 \text { alleles }}$

${ }^{\mathrm{b}}$ Patients were considered positive for the disease based on their clinical picture only

SBB and were positive for DQ2 and/or DQ8 haplotypes or any of their alleles.

Distribution of $D Q A 1 * 05, D Q B 1 * 02$ and $D Q B 1 * 03: 02$ alleles among confirmed patients and controls

The $D Q B 1 * 02$ allele was the most frequently encountered in confirmed CD patients $(84.6 \%)$ followed by $D Q A 1 * 05$ 
Table $5 D Q A 1 * 05, D Q B 1 * 02$ and $D Q B 1 * 03: 02$ alleles distribution in patients and controls

\begin{tabular}{llll}
\hline & $\begin{array}{l}\text { Confirmed cases } \\
(n=65)\end{array}$ & $\begin{array}{l}\text { Controls } \\
(n=97)\end{array}$ & $P$ value \\
\hline$D Q A 1 * 05$ allele & & & \\
Positive & $52(80 \%)$ & $53(54.6 \%)$ & 0.002 \\
Negative & $13(20 \%)$ & $41(42.3 \%)$ & 0.000 \\
$D Q B 1 * 02$ allele & & $56(57.7 \%)$ & \\
$\begin{array}{l}\text { Positive } \\
\text { Negative }\end{array}$ & $55(84.6 \%)$ & & \\
$D Q B 1 * 03: 02$ allele & $28(28.9 \%)$ & 0.185 \\
Positive & $13(20 \%)$ & $69(71.1 \%)$ & \\
Negative & $52(80 \%)$ & & \\
\hline
\end{tabular}

allele $(80 \%)$ and $D Q B 1 * 03: 02$ allele $(20 \%)$. On the other hand, $D Q A 1 * 05$ allele was the most frequently encountered in control individuals $(54.6 \%)$ followed by $D Q B 1 * 02$ allele (42.3\%) and last by $D Q B 1 * 03: 02$ allele $(28.9 \%)$. The difference in frequency of $D Q A 1 * 05$ and $D Q B 1 * 02$ between confirmed patients and controls was statistically significant ( $P=0.001$ and $P=0.000$, respectively), while it was not significant for $D Q B 1 * 03: 02$ allele $(P=0.203$; Table 5).

Assuming Hardy-Weinberg equilibrium, allele frequencies were estimated from the percentage of individuals that carry the allele, using the Hardy-Weinberg equation $\left(p^{2}+2 p q+q^{2}=1\right)$. The estimated frequencies, in healthy controls, are $(32.6 \%)$ for $D Q A 1 * 05$, (24.0\%) for $D Q B 1 * 02$ and $(15.7 \%)$ for $D Q B 1 * 03: 02$.

\section{Distribution of DQ2 and DQ8 haplotypes among confirmed patients and controls}

The DQ2 haplotype is more frequent in CD patients (70.8\%) than in controls (17.5\%), while the DQ8 haplotype is more frequent in controls $(27.8 \%)$ than in $\mathrm{CD}$ patients (15.4\%). Statistical analysis for the distribution of DQ2 haplotype among patients and controls reveals that the frequency difference is statistically significant $(P=0.000)$. The distribution is not statistically significant for DQ8 haplotype $(P=0.064)$ and for coexisting DQ2 and DQ8 haplotypes $(P=0.615$; Table 6$)$.

\section{Discussion}

The diagnostic approach for CD in Gaza strip is based solely on serological or SBB tests. This approach does not meet the criteria of $\mathrm{CD}$ diagnosis published in different international guidelines such as NASPGHAN, ESPGHAN and BSG [1, 7, 19]. Based on these guidelines, a
Table 6 Frequency of DQ2 and DQ8 haplotype among patients and controls

\begin{tabular}{llll}
\hline Haplotype & $\begin{array}{l}\text { Confirmed cases } \\
n=(65)\end{array}$ & $\begin{array}{l}\text { Controls } \\
n=(97)\end{array}$ & $P$ value \\
\hline DQ2 & & & \\
Positive & $46(70.8 \%)$ & $80(82.5 \%)$ & 0.000 \\
Negative & $19(29.2 \%)$ & $27(27.8 \%)$ & 0.064 \\
DQ8 & & $70(72.2 \%)$ & \\
Positive & $10(15.4 \%)$ & $3(3.1 \%)$ & 0.615 \\
Negative & $55(84.6 \%)$ & $94(96.9 \%)$ & \\
DQ2 + DQ8 & & & \\
Positive & $3(4.6 \%)$ & $62(95.4 \%)$ & \\
Negative & &
\end{tabular}

combination of gluten-dependent clinical manifestations, CD-specific antibodies, HLA-DQ2 and DQ8 haplotypes and enteropathy should be included $[4,7,11,20]$. According to these guidelines only nine patients (8.9\%) were complying with the diagnostic criteria. Therefore, in our study, we only included patients who were positive for serological test or intestinal biopsy and were positive for DQ2 or DQ8 haplotypes or for a fraction of the DQ2 heterodimer $(D Q A 1 * 05$ or $D Q B 1 * 02$ allele) for the rest of statistical analyses. The patients who fulfilled these criteria were only 65 patients and were considered confirmed for having the disease.

Typing for HLA-DQ2 and DQ8 is considered a useful tool to exclude $\mathrm{CD}$ or to make the diagnosis unlikely in the case of a negative test result for both markers. Therefore, ruling out the expression of $D Q A 1 * 05, D Q B 1 * 02$ and $D Q B 1^{*} 03: 02$ is of critical importance for the exclusion of $\mathrm{CD}$ in suspected patients. In the current study eight patients (7.9\%) were negative for the three tested alleles, accordingly they were excluded from being CD patients and they may need an extra investigation to other diseases such as wheat sensitivity and non-coeliac gluten sensitivity. Noncoeliac gluten sensitivity is poorly characterized and still debated if it is even caused by gluten at all, as opposed to other components of wheat (i.e., amylase-trypsin inhibitors, fermentable oligo-, di-, mono-saccharides and polyols) $[21,22]$.

Positive serological tests and SBB are essential to the diagnosis of $\mathrm{CD}$ when the patient is on a gluten-containing diet $[1,19]$. In the current study, however, diagnosis of $2.4 \%$ of the Anti-EMA-positive (1/40), $12.9 \%$ of the biopsy-positive (4/27) and $12 \%$ of those diagnosed upon the clinical picture $(3 / 22)$ was ruled out (Table 4). This result questions the reliability of SBB alone to establish CD diagnosis in Gaza strip, probably due to lack of the proper expertise. Accordingly, serological and particularly genetic tests would be much-admired to establish more accurate 
CD diagnosis in similar settings with poor histopathological diagnostic capacity. This is consistent with previous studies which predicted incorrect diagnosis in absence of genetic predisposing alleles with biopsy confirmed cases $[23,24]$. Indeed, a recent large retrospective multicentre study conducted in Spain concluded that small bowel biopsy could have been avoided in a high proportion of symptomatic patients without any risk of misdiagnosis [13]. As a result, recent revisions of the criteria for $\mathrm{CD}$ diagnosis have addressed the increased contribution of HLA-DQ genotyping in addition to serology in CD diagnosis, especially for its high negative predictive value $[4,25,26]$.

The HLA-DQ2 and -DQ8 were, respectively, present in $70.8 \%$ and in $15.4 \%$ of CD patients in Gaza Strip compared to 17.5 and $27.8 \%$ in controls, respectively. Our results differ from those described in European populations, where the frequency of the HLA-DQ2 is higher than $90 \%$ and that of HLA-DQ8 ranges between 5 and 10\% [27, 28]. The frequency of DQ2 haplotype in controls (17.5\%) is consistent with other Arab populations (9.6-16.4\%) and European populations (14.1-9.6\%); and the frequency of DQ8 (27.8\%) is higher than in Arabs (10.2-14.3\%) and Europeans (7.3-14.5\%) as reported in the Allele Frequency Net Database [29].

Another finding from the present study was that 6 (9.2\%) of the 65 coeliac patients expressed neither the DQ2 nor DQ8 heterodimers. Three of them expressed the $D Q A 1 * 05$ allele and the remaining three expressed the $D Q B 1 * 02$ allele. Several previous studies have demonstrated that just one of the alleles $D Q A 1 * 05$ or $D Q B 1 * 02$, each coding for half of the DQ2 heterodimer molecule would confer a predisposition towards triggering $\mathrm{CD}$ [27, 30-32].

Assuming Hardy-Weinberg equilibrium, the allelic frequency could be calculated from the percentage of control individuals who possess the allele and compared to published frequencies for other populations in the Allele Frequency Net Database [29]. The calculated frequencies $(32.6 \%$ for $D Q A 1 * 05,24.0 \%$ for $D Q B 1 * 02$ and $15.7 \%$ for $D Q B 1 * 03: 02)$ came in the middle compared to other Arabs (13-37\% for $D Q A I^{*} 05,0-36 \%$ for $D Q B 1 * 02$ and $0-20.7 \%$ for $D Q B 1 * 03: 02$ ). Our frequencies are slightly different from the general population of North America (0-30\% for DQAI*05, 0-24\% for $D Q B 1 * 02$ and $9.6-77.8 \%$ for $D Q B 1 * 03: 02)$ and Europe $(0-40.8 \%$ for $D Q A 1 * 05,9-48 \%$ for $D Q B 1 * 02$ and $1.9-22 \%$ for $\left.D Q B 1^{*} 03: 02\right)$. Any discrepancy in the frequency of alleles between our population and other populations may be attributed to a number of factors including: ethnicity and reproductive attitudes (i.e., consanguinity).

\section{Conclusions}

Absence of HLA-DQ2 and HLA-DQ8 genotyping may result in $\mathrm{CD}$ misdiagnosis, particularly in a setting with poor histopathological diagnostic capacity.

In Gaza CD patients, the $D Q B 1 * 02$ is the most commonly encountered allele (84.6\%) followed by $D Q A 1 * 05(80 \%)$ and $D Q B 1 * 03: 02(20 \%)$. The $D Q A 1 * 05$ allele is the most commonly encountered in healthy control individuals $(54.6 \%)$ followed by $D Q B 1 * 02(42.3 \%)$ and $D Q B 1 * 03: 02(28.9 \%)$.

The HLA-DQ2 haplotype frequency is higher in patients $(70.8 \%)$ than in controls (17.5\%), while HLA-DQ8 is higher in controls $(27.8 \%)$ than patients $(15.4 \%)$.

Acknowledgements The authors wish to thank the chairperson of Ard El Insan Palestinian Benevolent Association Dr. Adnan Al Whaidi and its team for their valuable help in recruiting the participating patients and making their clinical data accessible for us.

\section{Compliance with ethical standards}

Ethical approval All procedures performed in studies involving human participants were in accordance with the ethical standards of the ethical committee of the Palestinian health research council (PHRC) and with the 1964 Helsinki declaration and its later amendments or comparable ethical standards. This article does not contain any studies with animals performed by any of the authors.

Informed consent Samples and data were collected after approval of Ard El Insan Palestinian Benevolent Association and consent of the patients and controls or their parents. Informed consent was obtained from all individual participants included in the study.

Conflict of interest The authors declare that they have no conflict of interest.

Open Access This article is distributed under the terms of the Creative Commons Attribution 4.0 International License (http://creative commons.org/licenses/by/4.0/), which permits unrestricted use, distribution, and reproduction in any medium, provided you give appropriate credit to the original author(s) and the source, provide a link to the Creative Commons license, and indicate if changes were made.

\section{References}

1. Ludvigsson JF, Leffler DA, Bai JC, Biagi F, Fasano A, Green PH, Hadjivassiliou M, Kaukinen K, Kelly CP, Leonard JN, Lundin KE, Murray JA, Sanders DS, Walker MM, Zingone F, Ciacci C (2012) The Oslo definitions for coeliac disease and related terms. Gut 62(1):43-52. https://doi.org/10.1136/gutjnl-2011-301346

2. Megiorni F, Pizzuti A (2012) HLA-DQA1 and HLA-DQB1 in Celiac disease predisposition: practical implications of the HLA molecular typing. J Biomed Sci 19:88. https://doi.org/10.1186/ 1423-0127-19-88

3. Kim CY, Quarsten H, Bergseng E, Khosla C, Sollid LM (2004) Structural basis for HLA-DQ2-mediated presentation of gluten epitopes in celiac disease. Proc Natl Acad Sci USA 101(12):4175-4179. https://doi.org/10.1073/pnas.0306885101

4. Husby S, Koletzko S, Korponay-Szabo I, Mearin M, Phillips A, Shamir R, Troncone R, Giersiepen K, Branski D, Catassi C 
(2012) European Society for pediatric gastroenterology, hepatology, and nutrition guidelines for the diagnosis of coeliac disease. J Pediatr Gastroenterol Nutr 54(1):136-160

5. Romanos J, van Diemen CC, Nolte IM, Trynka G, Zhernakova A, Fu J, Bardella MT, Barisani D, McManus R, van Heel DA, Wijmenga C (2009) Analysis of HLA and non-HLA alleles can identify individuals at high risk for celiac disease. Gastroenterology 137(3):834-840. https://doi.org/10.1053/j.gastro.2009.05.040 (840 e831-833)

6. Karell K, Louka AS, Moodie SJ, Ascher H, Clot F, Greco L, Ciclitira PJ, Sollid LM, Partanen J (2003) HLA types in celiac disease patients not carrying the DQA $1 * 05-\mathrm{DQB} 1 * 02$ (DQ2) heterodimer: results from the European Genetics Cluster on Celiac Disease. Hum Immunol 64(4):469-477

7. Husby S, Koletzko S, Korponay-Szabo IR, Mearin ML, Phillips A, Shamir R, Troncone R, Giersiepen K, Branski D, Catassi C, Lelgeman M, Maki M, Ribes-Koninckx C, Ventura A, Zimmer KP (2012) European Society for pediatric gastroenterology, hepatology, and nutrition guidelines for the diagnosis of coeliac disease. J Pediatr Gastroenterol Nutr 54(1):136-160. https://doi. org/10.1097/MPG.0b013e31821a23d0

8. Wolters VM, Wijmenga C (2008) Genetic background of celiac disease and its clinical implications. Am J Gastroenterol 103(1):190-195. https://doi.org/10.1111/j.1572-0241.2007.01471.x

9. Hadithi M, von Blomberg BM, Crusius JB, Bloemena E, Kostense PJ, Meijer JW, Mulder CJ, Stehouwer CD, Pena AS (2007) Accuracy of serologic tests and HLA-DQ typing for diagnosing celiac disease. Ann Intern Med 147(5):294-302

10. Rubio-Tapia A, Hill ID, Kelly CP, Calderwood AH, Murray JA (2013) ACG clinical guidelines: diagnosis and management of celiac disease. Am J Gastroenterol 108(5):656-676. https://doi. org/10.1038/ajg.2013.79 (quiz 677)

11. Ludvigsson JF, Bai JC, Biagi F, Card TR, Ciacci C, Ciclitira PJ, Green PH, Hadjivassiliou M, Holdoway A, van Heel DA (2014) Diagnosis and management of adult coeliac disease: guidelines from the British Society of Gastroenterology. Gut 63(8):1210-1228

12. Kaukinen K, Partanen J, Maki M, Collin P (2002) HLA-DQ typing in the diagnosis of celiac disease. Am J Gastroenterol 97(3):695-699. https://doi.org/10.1111/j.1572-0241.2002.05471.x

13. Donat E, Ramos JM, Sanchez-Valverde F, Moreno A, Martinez MJ, Leis R, Pena-Quintana L, Castillejo G, Fernandez S, Garcia Z, Ortigosa L, Balmaseda E, Marugan JM, Eizaguirre FJ, Lorenzo H, Barrio J, Ribes-Koninckx C (2015) ESPGHAN 2012 guidelines for coeliac disease diagnosis: validation through a retrospective Spanish multicentric study. J Pediatr Gastroenterol Nutr 62(2):284-291. https://doi.org/10.1097/MPG.0000000000000870

14. Biesiekierski JR, Newnham ED, Irving PM, Barrett JS, Haines M, Doecke JD, Shepherd SJ, Muir JG, Gibson PR (2011) Gluten causes gastrointestinal symptoms in subjects without celiac disease: a doubleblind randomized placebo-controlled trial. Am J Gastroenterol 106(3):508-514. https://doi.org/10.1038/ajg.2010.487 (quiz 515)

15. Lundin KE, Alaedini A (2012) Non-celiac gluten sensitivity. Gastrointest Endosc Clin N Am 22(4):723-734. https://doi.org/ 10.1016/j.giec.2012.07.006

16. Ludvigsson JF, Bai JC, Biagi F, Card TR, Ciacci C, Ciclitira PJ, Green PH, Hadjivassiliou M, Holdoway A, van Heel DA, Kaukinen K, Leffler DA, Leonard JN, Lundin KE, McGough N, Davidson M, Murray JA, Swift GL, Walker MM, Zingone F, Sanders DS (2014) Diagnosis and management of adult coeliac disease: guidelines from the British Society of Gastroenterology. Gut 63(8):1210-1228. https://doi.org/10.1136/gutjnl-2013-306578

17. Ruby AM, Al-Khodary R, Shubair M, Sirdah M (2014) Immunodiagnosis of celiac disease among children with chronic diarrhea in Gaza Strip, Palestine. Am J BioSci 2(6):4

18. Profaizer T, Eckels D, Delgado J (2011) Celiac disease and HLA typing using real-time PCR with melting curve analysis. Tissue Antigens 78(1):31-37
19. Hill ID, Dirks MH, Liptak GS, Colletti RB, Fasano A, Guandalini S, Hoffenberg EJ, Horvath K, Murray JA, Pivor M, Seidman EG (2005) Guideline for the diagnosis and treatment of celiac disease in children: recommendations of the North American Society for Pediatric Gastroenterology, Hepatology and Nutrition. J Pediatr Gastroenterol Nutr 40(1):1-19

20. Hill ID, Dirks MH, Liptak GS, Colletti RB, Fasano A, Guandalini S, Hoffenberg EJ, Horvath K, Murray JA, Pivor M (2005) Guideline for the diagnosis and treatment of celiac disease in children: recommendations of the North American Society for Pediatric Gastroenterology, Hepatology and Nutrition. J Pediatr Gastroenterol Nutr 40(1):1-19

21. Henggeler JC, Veríssimo M, Ramos F (2017) Non-coeliac gluten sensitivity: a review of the literature. Trends Food Sci Technol 66:84-92. https://doi.org/10.1016/j.tifs.2017.05.018

22. Volta U, Caio G, Karunaratne TB, Alaedini A, De Giorgio R (2017) Non-coeliac gluten/wheat sensitivity: advances in knowledge and relevant questions. Expert Rev Gastroenterol Hepatol 11(1):9-18. https://doi.org/10.1080/17474124.2017.1260003

23. Kapitany A, Toth L, Tumpek J, Sipos E, Woolley N, Partanen J, Szegedi G, OlÁh É, Sipka S, Korponay-szabÓ I (2006) Diagnostic significance of HLA-DQ typing in patients with previous coeliac disease diagnosis based on histology alone. Aliment Pharmacol Ther 24(9):1395-1402

24. Anderson RP, Henry MJ, Taylor R, Duncan EL, Danoy P, Costa MJ, Addison K, Tye-Din JA, Kotowicz MA, Knight RE (2013) A novel serogenetic approach determines the community prevalence of celiac disease and informs improved diagnostic pathways. BMC Med 11(1):1-13

25. Hadithi M, Von Blomberg BME, Crusius JBA, Bloemena E, Kostense PJ, Meijer JW, Mulder CJ, Stehouwer CD (2007) Accuracy of serologic tests and HLA-DQ typing for diagnosing celiac disease. Ann Intern Med 147(5):294-302

26. Kurppa K, Salminiemi J, Ukkola A, Saavalainen P, Löytynoja K, Laurila K, Collin P, Mäki M, Kaukinen K (2012) Utility of the new ESPGHAN criteria for the diagnosis of celiac disease in atrisk groups. J Pediatr Gastroenterol Nutr 54(3):387-391

27. Karell K, Louka AS, Moodie SJ, Ascher H, Clot F, Greco L, Ciclitira PJ, Sollid LM, Partanen J, Disease EGCoC (2003) HLA types in celiac disease patients not carrying the DQA $1 * 05-\mathrm{DQB} 1 * 02$ (DQ2) heterodimer: results from the European Genetics Cluster on Celiac Disease. Human Immunol 64(4):469-477

28. Tye-Din J, Anderson R (2008) Immunopathogenesis of celiac disease. Curr Gastroenterol Rep 10(5):458-465

29. Gonzalez-Galarza FF, Takeshita LY, Santos EJ, Kempson F, Maia MH, da Silva AL, Teles e Silva AL, Ghattaoraya GS, Alfirevic A, Jones AR, Middleton D (2014) Allele frequency net 2015 update: new features for HLA epitopes, KIR and disease and HLA adverse drug reaction associations. Nucleic Acids Res 43(Database issue):D784-788. https://doi.org/10.1093/nar/gku1166

30. Kagnoff MF (2007) Celiac disease: pathogenesis of a model immunogenetic disease. J Clin Investig 117(1):41-49

31. Polvi A, Arranz E, Fernandez-Arquero M, Collin P, Maki M, Sanz A, Calvo C, Maluenda C, Westman P, de la Concha EG, Partanen J (1998) HLA-DQ2-negative celiac disease in Finland and Spain. Hum Immunol 59(3):169-175

32. Mubarak A, Spierings E, Wolters V, van Hoogstraten I, Kneepkens CF, Houwen R (2013) Human leukocyte antigen DQ2. 2 and celiac disease. J Pediatr Gastroenterol Nutr 56(4):428-430

\section{Publisher's Note}

Springer Nature remains neutral with regard to jurisdictional claims in published maps and institutional affiliations 